\title{
ARTICLE
}

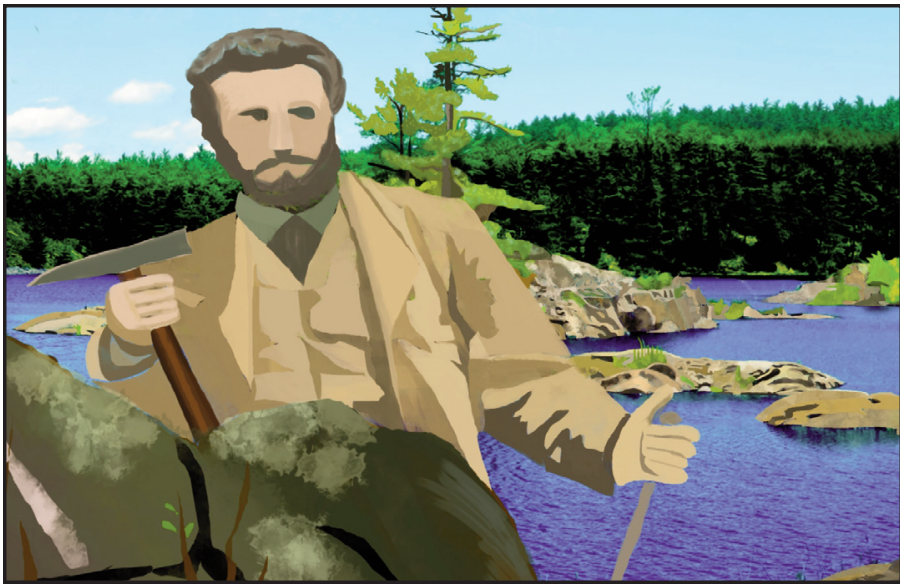

\section{"ALL THAT GLITTERS...:" The Scientific and Financial Ambitions of Robert Bell at the Geological Survey of Canada}

\author{
Brookes, Ian A. ${ }^{+}$ \\ Geography Department \\ York University, Toronto, Ontario \\ M3J 1P3, Canada
}

+ Ian Brookes, passed away February 13 ${ }^{\text {th }}, 2015$, and is missed by the Canadian Geoscience Community. This paper was submitted, reviewed and revised prior to his passing, and was finalized for publication by the generous efforts of his colleagues Ian Spooner and Antony R. Berger.

\section{SUMMARY}

In Canada, the $19^{\text {th }}$-century development of sciences with a geographical component was marked by individuals whose contributions were remarkable for their details, their geographical coverage, the originality and longevity of their ideas. Collectively, these individuals could be called the inventors of Canada.' Among them was Robert Bell. Early in his career at the Geological Survey of Canada and during an interval of part-time service while he taught at Queen's University (186468), Kingston, Ontario, Robert Bell (1841-1917) involved himself in several commercial schemes that he hoped would lead to the development of mineral occurrences in the British colony of Newfoundland (various minerals), Canada East and West (petroleum), and Nova Scotia (gold), developments that he hoped would also raise his financial as well as his scientific stature. Here, the circumstances of these ventures and their outcomes and his unencumbered achievements in later life are reviewed.

\section{RÉSUMÉ}

Au Canada, au 19e siècle, le développement des sciences comprenant un volet géographique a été marqué par des individus dont les contributions ont été remarquables par leurs détails, leur couverture géographique, leur originalité, et la longévité de leurs idées. Collectivement, ces personnes pourraient être appelées les «inventeurs du Canada». Parmi elles se trouvait Robert Bell. Tout au début de sa carrière à la Commission Géologique du Canada, et pendant son service à temps partiel alors qu'il enseignait à l'université Queen's à Kingston, Ontario (1864-1868), Robert Bell (1841-1917) s'est impliqué personnellement dans plusieurs programmes commerciaux qu'il espérait mener au développement des richesses minérales de la colonie britannique de Terre-Neuve (divers minéraux), du Canada-Est et Canada-Ouest (pétrole), et de la NouvelleEcosse (or). Il espérait que ces développements augmenteraient son statut financier ainsi que scientifique. Dans cet article, la situation de ces entreprises et leurs résultats, et ses accomplissements scientifiques indépendants, sont passés en revue.

Traduit par le Traducteur

\section{INTRODUCTION Objective}

Robert Bell's 50-year career with the Geological Survey of Canada (GSC) left him with a dual reputation in the history of Canadian Geology; on the one hand, as the farthest-travelled explorer of Canada of his times and author of a landmark synthesis: On Glacial Phenomena in Canada (Bell 1890); on the other hand, as a fractious schemer against Director William Logan's successors, Alfred Selwyn and George Dawson, and knowing seeker of financial gain in ventures stemming from his and others' geological investigations. The paper examines this duality.

\section{Young Bell at the Geological Survey of Canada}

In 1857, shortly before his $16^{\text {th }}$ birthday, Robert Bell (18411917; Fig. 1) was recruited into the Geological Survey of Canada (GSC) by its Director, Sir William Logan (1798-1875), following the early death of his father, Andrew, a Presbyterian minister and noted amateur geologist. Bell met with early 


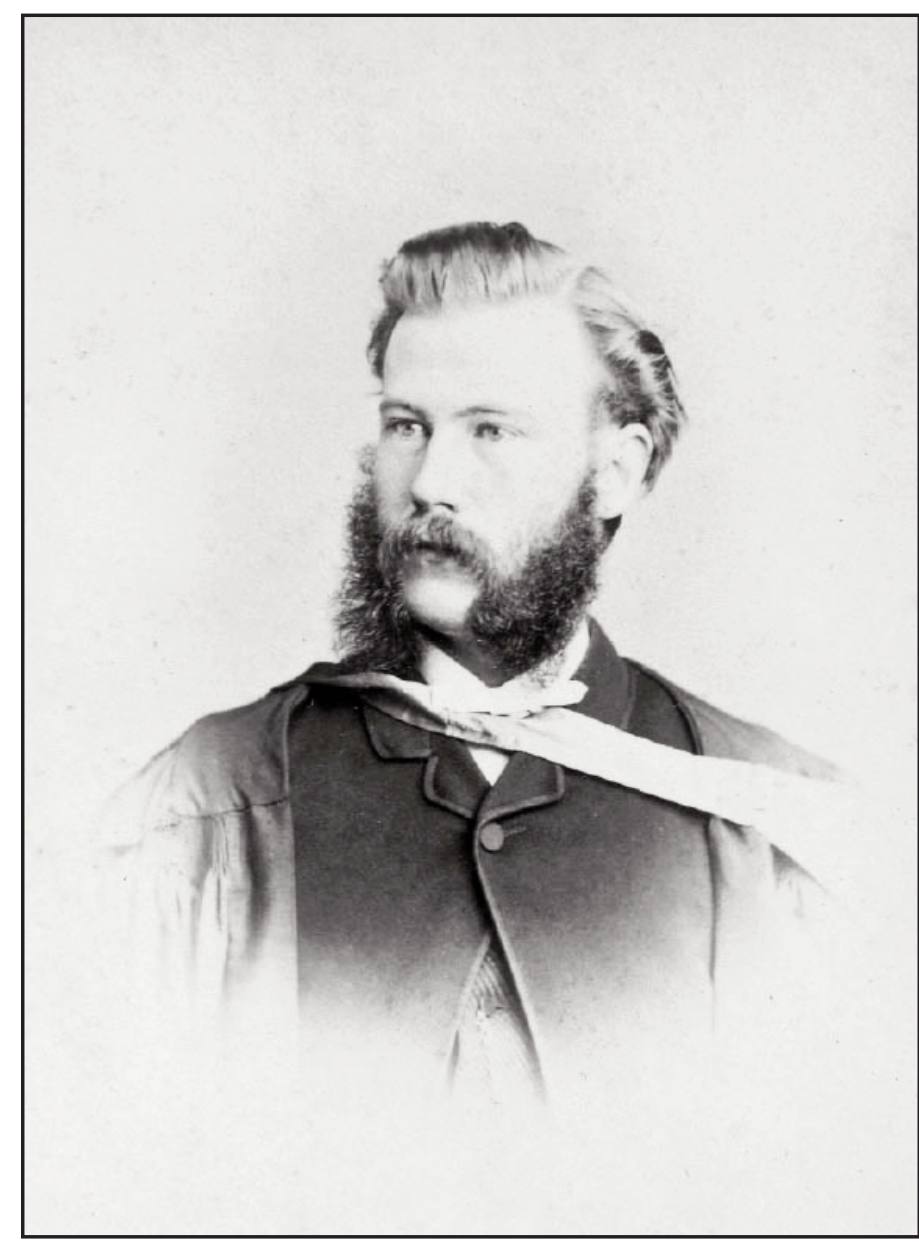

Figure 1. Robert Bell, Montreal, QC, 1865. McCord Museum, McGill University, Notman Collection, catalogue no. I-17981.1

approval at the Survey, then based in Montréal. Although his duties were those of assistant to field parties, he published eight articles in his first four years on Natural History materials collected on his first two explorations (Bell 1858, 1859a, b, 1861a, b, c, d, e).

Such was that early approval that in 1858, with Logan's encouragement, Bell enrolled part-time at McGill University, where, for a year, there being no Geology program, he studied for the certificate in Civil Engineering. At the same time, and for the following two years, he attended lectures in Geology given by McGill's recently appointed Principal, J. William Dawson (1820-1899). He graduated in Civil Engineering in 1861, with as much Geology as an established degree program would then have been able to offer, but no degree.

Prior to his studies, Bell would have known of Logan's embrace of the Glacier Theory (first announced officially in Logan 1847), while Principal Dawson was a life-long adherent to the Drift Theory (e.g. Dawson 1866). Admiration of Logan was general amongst Survey staff, including young Bell, for more than scientific reasons, which may have influenced him to follow Logan's glacier leanings on his field explorations. After Bell's first three years as assistant, Logan was confident enough in him that he assigned him solo fieldwork. As well, in 1862, burdened with administration, fundraising, and international exhibitions, Logan assigned Bell the task of writing a section on 'Superficial Deposits' for the volume being pre- pared to summarize the Survey's first 20 years' work (Logan et al. 1863). The volume was published just as Bell took up a fiveyear professorship at Queen's University at Kingston (186468; Brookes 2011), establishing him then as one of the few authoritative Canadian adherents to 'Glacierism.'

\section{Seeking Status}

I posit several influences on Bell's early-career pursuit of financial as well as scientific status. First, his concern for the reputation of the GSC as an engine of Canada's economic development, which lay at the root of its establishment in 1842, the year following the constitution at Westminster of the Province of Canada from the former 'Upper' and 'Lower' Canadas. The Industrial Revolution had by then been in progress for two generations; the United States was expanding rapidly on its rich (and richly surveyed) resource endowment (e.g. Pennsylvania coal and Superior iron ore). North of the border the search for the Carboniferous system above the Devonian rocks had drawn blanks, while iron ore in the crystalline 'Azoic' (Precambrian) rocks occurred only as small bodies of sulfide, which could not be smelted at large enough scale until the Bessemer process arrived in North America in the 1860s.

On Manitoulin Island, in Georgian Bay of Lake Huron (Fig. 2), Logan's lieutenant, Alexander Murray (1810-1884), recognized the association of petroliferous seeps with lowamplitude anticlines in the Paleozoic limestone-shale sequence (Murray 1847), while Logan (1846) reported seeps in the Gaspé Peninsula (Fig. 2); both occurrences attracted capitalists. Capitalism was - had to be - to the fore at all levels of society at this time, especially concerning mineral resources, although the American Civil War was depressing the economy north of the border. Although most noted for his glacial and forest studies, economic minerals and mining were never very far down on Murray's ‘to-do' list - field and office.

Second, with the fortunes accruing during the California Gold Rush of 1849, and the Silver Boom a decade later, Canada-to-be experienced its own 'rushes' - placer gold in the Fraser Valley in 1858, in the Cariboo District in 1861, in the colony of British Columbia, and, more hesitantly, after 1858 discoveries, vein gold in Nova Scotia. During his years at Queen's University, again as private not public servant, Bell found himself conveniently placed to involve himself in Scotian gold.

Third, while again as private citizen, Bell sought financial gain from mineral developments in Newfoundland. Relations between the Province of Canada and Britian's oldest colony became close geologically when, in response to a British request in 1864, Logan seconded Alexander Murray to head a geological survey of the Island. Formal institutional heft behind discovery of mineral resources in Newfoundland, in Logan's mind to Canada's advantage, was seen as an enticement to Newfoundland's joining the Canadian confederation being formulated that year in conferences at Charlottetown and Québec.

With these institutional encouragements, identification of personal influences on Bell's monetary pursuits must necessarily be loaded with subjectivity. Nevertheless, three such influences are posited here.

First, Bell's upbringing was in no way moneyed; his father was a poorly paid, intellectual cleric who was married as 

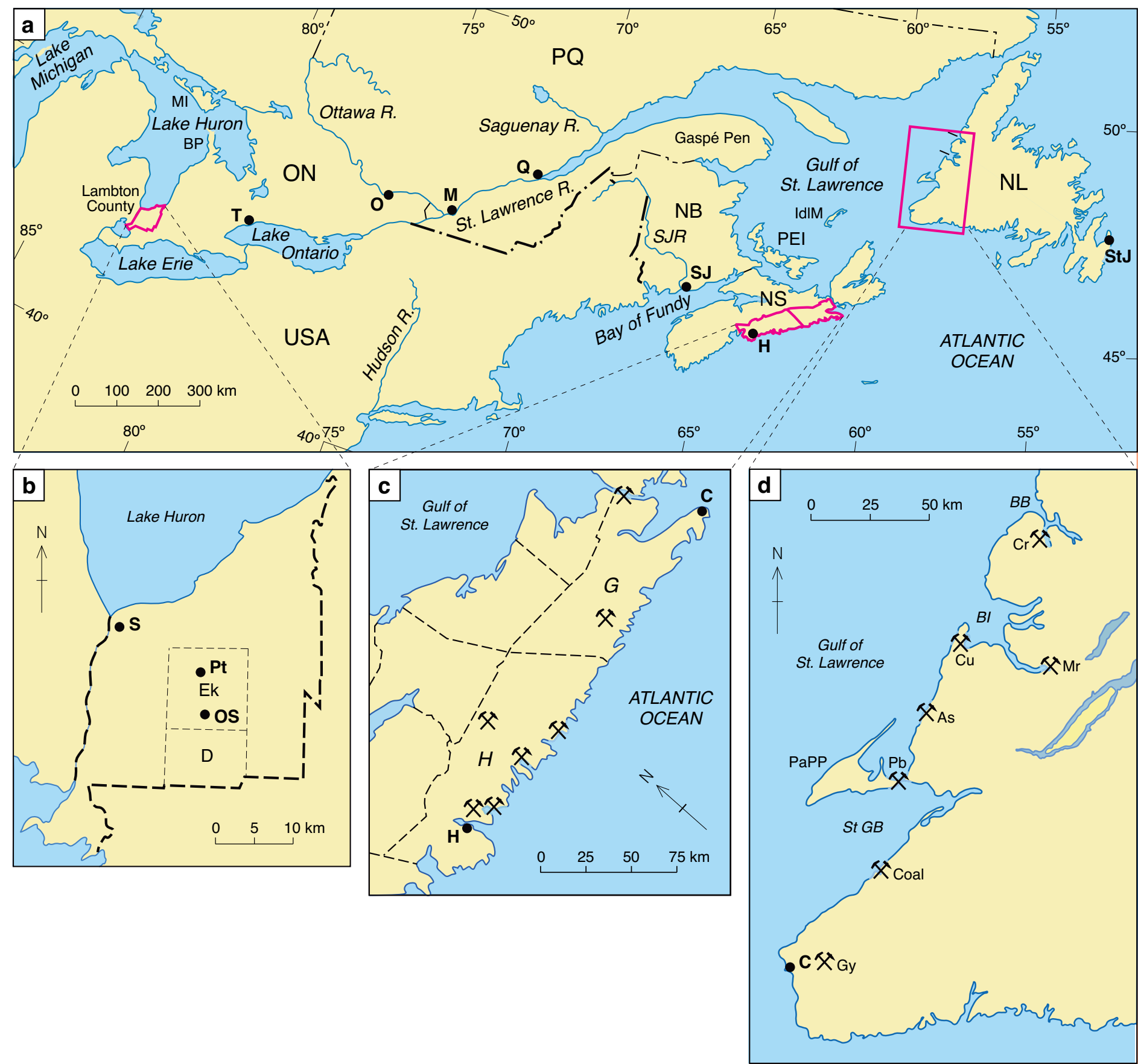

Figure 2. (a) Eastern Canada, showing (red outline) locations of mineral occurrences in which Robert Bell was involved. Cities mentioned in text: $\mathrm{T}$ (Toronto), $\mathrm{O}$ (Ottawa), M (Montréal), Q (Québec), H (Halifax), SJ (Saint John), St.J (St. John's), IdlM (Iles de la Madeleine), MI (Manitoulin Island), SJR (Saint John River). (b) Historical oil-producing region of Canada West: S (Sarnia), Lambton County (dashed boundary); Ek (Enniskillen Township), D (Dawn Township), Pt (Petrolia), OS (Oil Springs). (c) 1860's gold mining in Nova Scotia (hammer symbols), H (Halifax), C (Canso); county boundaries: H (Halifax County), G (Guysborough County). (d) Southwest Newfoundland, places visited by Richardson's Geological Survey of Canada party, 1867: C (Codroy), St GB (St. George's Bay), BI (Bay of Islands), BB (Bonne Bay), PaPP (Port au Port Peninsula); mineral occurrences (hammer symbol): Gy (gypsum), Coal, Pb (lead sulfide), As (chrysotile asbestos), Cu (York Harbour copper sulfide), Mr (Humbermouth marble), Cr (Bonne Bay chromite).

strongly to his Natural History pastimes as to his ministry. He instilled Presbyterian as well as scientific values in Robert and his younger brother, John. His mother was a lawyer's daughter, who must originally have seen in her suitor both moral and intellectual, rather than financial, comfort - a functional partnership at least, curtailed prematurely after 18 years by Andrew's death from one of the common and incurable bronchial infections then so prevalent. Natural History, therefore, was to be Bell's intellectual and (small ' $r$ ') religious path.
Bell practiced his Presbyterianism as professional pursuits allowed; for example, in scores of letters home from his explorations there is no mention anywhere of religious observances by him, or exhortations to the family. At home for the 'office' part of the year he regularly attended St. Andrew's church with the family, and was thought of highly enough there to have a wall-plaque dedicated to his memory. Then, while Darwin's 'The Origin of Species' first appeared (1859) during his McGill studies, and was one of his graduation prizes, its thesis was 
never evident in Bell's writings. He taught at Queen's University from 1864-689 (Brookes 2011); in a 'Prologue' written for his Natural History course at Queen's he clearly saw 'Creation' as 'Divine,' but, nevertheless, 'Nature' revealed herself to 'Science.'

Second, his first years at the Survey (the late 1850s), he received (irregularly) the equivalent of about $\$ 2.00$ a day from Logan's pocket it seems, which was enough only to feed him. Robert, therefore, must early have sensed that maintenance of both social and financial status was going to depend on belonging to the upper middle-class, and that this had implications to income. Brother John obtained the Medical Doctorate degree from McGill at age 21, and thus was not going to suffer financially, although he early showed an humane concern for patients from the working poor of Montréal. John died in 1878 , aged 33, of a bronchial affliction, but likely remained to Robert an example of secure social status. In that year (1878) Robert himself was awarded the MD from McGill, which is seen by most as his response to sicknesses among Native peoples, whom he respected as guides, canoe men, and victuallers of his Survey explorations.

Third, in 1864, at 23, Robert visited a Glasgow family, to the matriarch of which his mother, a Notman, was distantly related. The Smith family, with 14 children, was headed by the successful owner of an engineering company with local and Caribbean customers, particularly for railway rolling stock, rails, and bridges. Nine years later (1873) Bell married into this family, approaching $32-13$ years the senior of his spouse, Agnes - and would have wished to keep her in the comfort in which she was raised. This took some time; for instance, it was 20 years before home ownership replaced rental, six years before a child arrived, a second more than two years later, eventually growing to four. The Bells employed live-in girls as domestic help or for childcare. Even then, on his superannuation from the Survey in 1908, Bell's wealthy son-in-law, of the Douglas family (known to McGill for Douglas Hall, and to Queen's for the Douglas Library), agreed to assume the mortgage on the Bell home at 136 MacLaren Street, Ottawa (one street south of Somerset Street).

\section{FINANCIAL PATHWAYS Newfoundland}

In 1839-40, Joseph Beete Jukes undertook a geological survey of Newfoundland for the British Government, in which he identified several mineral occurrences, those on the island's west coast being more exploitable, if only for their coastal exposure (Jukes 1840, 1842; Martin 1983; Cuff and Wilton 1993). Then, in 1860, James Richardson of the GSC had surveyed the coasts of southern Labrador and the northwest of the Island. In 1867, therefore, Richardson was the natural leader of a party to follow-up Jukes' discoveries. The roles of the GSC and private interests in this expedition were intertwined. Montréal banker, Donald Ross, who was interested in the occurrence of coal in the hinterland of St. George's Bay (Fig. 2d), funded commission of a Gaspé schooner and its victualling, as well as recruitment of crew and labourers. Robert Bell and his freshly-minted physician brother, John (as botanist), made up the complement of seven. Director Logan perhaps felt political influence on his turning a blind eye to this privately funded 'expedition' - after all, it was not to Canada, and no Survey report of it was issued. Aside from banker Ross' commercial interests, the expedition could be seen as a 'private' part of Canada's enticement of Newfoundland to join the Confederation, which was enacted that year. As for Bell's participation, Logan probably also saw it as good experience for him.

With logistics arranged, they sailed from Gaspé, Québec, southeast to Iles de la Madeleine, in mid-Gulf of St. Lawrence (Fig. 2a), but nothing survives of investigations there. From there, the southwestern tip of Newfoundland was due east. Near Cape Anguille, Newfoundland, the southwest extremity of the island, on June 15 they checked on Jukes' report of a cliff exposure of gypsum near Codroy, a French fishing station near the southwest limit of the 'French Shore' (Rowe 1980; Hillier 1996). Murray, then in his third year of Newfoundland Survey, had also visited it (Murray 1866, in Murray and Howley 1881). Jukes had referred to 'vast masses' of gypsum, but the outcrop in the sea-cliff is only about 100 metres wide, and, if its associated karstic dolines define its inland extent, this amounts only to $\sim 100 \mathrm{~m}$. Besides acting as a soil conditioner for the alkaline soils of Canada West, where gypsum was already plentiful, the small size of the Newfoundland occurrence meant that its economic value was not then great, nor would it ever be (although Murray later discovered a huge gypsum body further north, inland of St. George's Bay, Newfoundland, which was worked until 2007 for wallboard manufacture at Corner Brook).

To the north, 2 miles inland of the St. George's Bay shore, Jukes had recorded two seams of coal in the banks of Middle Barachois and Robinsons rivers (Fig. 2d), which had been known from Captain Cook's surveys, exactly a century before the Richardson party's visit. Of the 12 seams eventually known (Howley 1896), Richardson's party sampled two 2-foot seams, and located the adit that Hugh Allan (owner of the shipping line) and Robert Russell (surveyor of Canada East) had driven into Robinsons River bank 10 years earlier.

As with Logan in the Canadas 20 years before, Murray's main mission in Newfoundland was the location of coal to fuel industrial development, marine and rail transport. If enough of it could be proven at the three west Newfoundland localities where it was known, its utility for a trans-island railway was obvious; as well, despite it being shallow and sandy, Bell optimistically praised St. George's Harbour for docking coal-ships, and the neighbourhood of the community there as a fuelling depot for a railway. Although it was surveyed ten years later (1877), a railway was not completed for another twenty (1898). Coal in commercial quantities eventually proved lacking on the island, while mines on Cape Breton Island came to supply most eastern Canadian demand.

Inland of St. George's, during hydrographic survey of Newfoundland, Captain Cook had in 1767 raised a cairn for survey purposes on a dome-shaped hill which later became 'Steel Mountain' (anomalously, 'Cairn Mountain' is named nearby). The Richardson party would have seen that the constituent rock was made almost entirely of feldspar (Bell called it 'labradorite', although it is not iridescent). More to the point toponymically, it contained 'blebs' up to a foot across of pure magnetite, the richest of the iron ores, yielding up to $70 \%$ metal. Technological lag in smelting technique, and access to more easily capitalized iron ores, excluded development of this 
rich but small occurrence - that is, until its high specific gravity and accessibility to St. George's Harbour permitted its exploitation in the late 1990s as ballast for the gravity-based structure of the Hibernia offshore oil platform.

Other small mineral occurrences were revisited by the Richardson party (Fig. 2d) - lead and zinc sulfides at Lead Cove, at the eastern end of the Port au Port Peninsula; to the north, below the Lewis Hills, chrysotile asbestos as beach boulders, derived from outcrops in the cliffs above; copper ore had for decades been staked and intermittently worked at York Harbour, just inside the Bay of Islands; high quality marble outcropping in the gorge of the Humber River at the head of that bay had earlier been claimed by St. John's interests, but other marbles were already being imported into Newfoundland for monuments. Upstream, 'pine-clad hills' noted in Cook's survey, and subsequently exploited for boat-building, had been succeeded by healthy stands of balsam fir, black and white spruces, and larch.

The last occurrence visited by the party had been recorded a few years before by Henry Youle Hind. After successfully fulfilling his geographical mandate on two expeditions on the Interior Plains in 1857 and 1858 (Hind 1860), Hind had semiretired to Windsor, Nova Scotia, from where he engaged in mineral surveys for promoters eager for enthusiastic appraisals of their prospects (e.g. Hind 1870). Contracted for mineral exploration by the Reid Company of Scotland and St. John's, Newfoundland, he had found chromite associated with ultramafic rocks at Bonne Bay, north of Bay of Islands (Fig. 2d). He had informed Rev. Moses Harvey of St. John's, fierce promoter of the colony's economic and social development in Presbyterian minister's clothing (e.g. Harvey 1873). In response to Bell's announcement of the GSC visit to the west coast, Harvey wrote to him: "... on the recommendation of Prof. Hind, I took out on my own account, under the old Act, five mining licences, in Bonne Bay, covering 15 sq miles. The licences hold good still as they are on the French shore. I never could get them examined. They are in serpentine rock and Hind had a high opinion of the locality, and drew out the diagram for me. What do you think of having Bay of Islands and Bonne Bay examined?" ... I should be willing to transfer my licences to your syndicate...we shall keep all secret"! (Library and Archives Canada (LAC), Robert Bell Fonds, MG29.15, v. 21.64, MH to RB, 18 April 1867). Bell, it seems, had mentioned to Harvey the organization of a group of investors at Kingston, more of which (below) awaited his involvement in Nova Scotia gold prospects. Bell had done his homework on most of these Newfoundland mineral and timber occurrences. He had corresponded with or knew the lease-holders of some of them, and likely knew of the precarious balance between their development and collapse.

As well as local economic disincentives for development of these several mineral occurrences in west Newfoundland, the most effective barrier was the exclusive right the French claimed through the Treaty of Versailles (1783), to fish and process the catch on this coast - the 'French Shore' - until 1904. This is no place even to outline the convoluted history of political entanglements arising from the various treaties (Utrecht 1713, Paris 1763, and Versailles 1783) aimed mainly at compensating the French for losses of their North American territories (but, see: Rowe 1980; Hillier 1996).
In January 1869, after five years of teaching at Queen's (Brookes 2011), but still six months before he rejoined the Survey, Bell returned to Newfoundland, staying a few months in St. John's, intending to curry favour among prominent businessmen and politicians for development of mineral and timber resources in the colony, in the hope of personal gain as advisor to and/or go-between for capitalists and government (Brookes 2010).

The circumstances of his visit to St. John's are cloudy; much was necessarily unspoken, conducted privately, and/or hastily. First, as soon as he arrived (January 21) Moses Harvey presented him with an invitation to himself 'and Friend' to a Robert Burns Supper to be held four days later. Harvey followed this immediately with an introduction to a young lady, who, however pretty or well-connected, could, of course, not be refused as the 'Friend.' Another invitation soon appeared: for him and 'companion' to attend a dinner at Government House, where local confederates had arranged for him to give a pro-Confederation address to the St. John's Athenaeum. Some months later the House of Assembly voted 21 to 9 against the confederation question, the attitude being 'Come Near At Your Peril, Canadian Wolf,' the anti-confederate ditty (http://www.heritage.nf.ca/articles/politics/anti-confederatesong.php).

As the originator of both of these invitations to Bell, Moses Harvey was probably repaying him for his earlier successful recommendation of his two sons to McGill University's Civil Engineering course. Then, there would have been his gratitude for Bell's supportive boost of the colony's economic development. Alexander Murray's position, meanwhile, as Director of the Newfoundland Geological Survey, prevented him from actively supporting Bell's commercial objectives, but he was, as always, ready to advertise his surveys' discoveries of minerals, timber, and land for settlement. Bell balanced these efforts, joining by request a covey of British doyens of Geology (Murchison, Archibald Geike, Ramsay, Bigsby) in recommending to a select committee of the colonial government the continuation and augmented funding of Murray's praiseworthy first five years of survey. But, discussions with politicians in the town (who were usually business leaders as well) did not go well, as a majority were more interested in retaining Newfoundland resources for development by Newfoundlanders, as well as mindful of the international consequences of contesting the French interpretation of the aforementioned treaties.

Bell stayed three months in St. John's, but it is hard to imagine he was engaged in these discussions the whole time. The space might be filled with reference to a letter Harvey wrote to Bell 20 months later, telling him of the disappointment, dismay, and ultimate depression suffered by Bell's young lady 'companion' at his departure, when, so it would seem, she had thought she had cause to hope for a continuing relationship (Brookes 2010).

\section{Petroleum Canada East - Québec}

Logan's early unsuccessful search for coal in the Gaspé region (Logan 1846) had noted oil seeps around Gaspé Bay with which local people, as everywhere it was found, caulked their boats and/or lighted their homes. By the 1860s, oil had attracted the attention of Montréal banker Donald Ross and others, 
while Bell was never far from discussions. He recorded the gist of an evening's conversation at Kingston in February 1866 with Willis Russell, then a mining engineer, later SurveyorGeneral of Québec. The evening included reading of a report on Gaspé petroleum geology by the noted American geologist, J. Peter Lesley, according to whom Gaspé offered prospects as good as any of the regions of eastern North America then being prospected for petroleum, Pennsylvania included. Lesley's reasons for this judgment read as modern as any that would be given today, but was he being honest? Had he agreed to 'talk up' Gaspé oil for personal gain?

Gaspé was ripe for investment and would produce 1-5 barrels of oil a day. Miniscule as this seems today, before its use to fuel the internal combustion engine, petroleum mainly lighted and lubricated, so this output could be seen, at least in the short term, as economically viable, particularly as it could replace diminishing whale-oil supplies. Engineer Russell urged Logan to press ahead with surveys and assays which would excite more attention - a typical attitude, when his remuneration depended on production. Logan, however, was circumspect, perhaps because the source of the oil seeps was invisible, so that the factors which so encouraged Lesley could not be confirmed. A fragment of evidence of Bell's not always transparent dealings in mineral development comes from a letter of 1866 in which he agreed to alter a report he made on Gaspé oil for Gaspé Bay Mining Co. of Belleville, in Canada West, in order to throw a more favourable light on the prospect (LAC, RB Papers, v. 24.98, RB to J. L. Macdonald, n.d., est. 1866). At this time, William B. Fowle, a Boston mining promoter, in a letter to Bell referred to having Bell's 'book' with him in London (Bell 1865a or b), where it would assist in negotiations with potential investors; "I sincerely trust that our mutual efforts may result in pecuniary success to all interested." (LAC, RB Papers, v. 19.69 WBF to RB, 20 March 1866).

A century and more later, the continuing refinement of tectonic theory and seismological technique have improved knowledge of the geological structure of on- and off-shore western Newfoundland, Gaspé, and mid-Gulf of St. Lawrence, to the point that these have once more become oil and gas exploration-grounds with the modern accompaniment of political conflict.

\section{Canada West - Ontario}

In 1859, Logan assigned Bell the solo task of following up Murray's initial exploration of Manitoulin Island, in Ontario's Georgian Bay of Lake Huron (Fig. 2a; Murray 1847; Bell 1870). The Manitoulin survey brought out in Bell the 'complete natural historian,' reflected in his copious notes on bedrock, glacial grooves, hydrographic patterns in relation to geologic structure, ancient lake terraces, climatic anomalies, and Indian agriculture (Indians had been resettled on Manitoulin from their lands which were taken up for immigrant settlement). For present purposes, the most important influence on Bell was his first encounter with the petroliferous seeps, which Murray had related to low-amplitude anticlinals. The previous year, oil-shale operations had opened at Craigleith, near Collingwood, on the southern shore of Georgian Bay, and Logan was showing interest in small 'gushers' in southwestern Canada West. There, in the 1860's, petroleum substituted for gold as the focus of frenetic speculation. Petroleum was most obvious in Enniskillen and Dawn Townships of Lambton Co. (Fig. 2b), and in Orford Township, Kent Co., Enniskillen produced 82,000 barrels of oil in 1862 (Logan et al. 1863), which put in perspective the estimated 1-5 barrels a day (<1800 bbl p.a.) from the Gaspé. In his brother John's name, Bell purchased 200 acres of land in Enniskillen, Concession 7 , Lot 18, where oil was suspected beneath, but he was already trying to sell it in 1864, by which time he had learned that it was not in the oil-rich concessions proven by drilling. As well, the American Civil War was depressing prices. Bell's interest in this oil-field led him to write a popular pamphlet on petroleum (Bell 1865c), which he dedicated to Logan, telling him that it was intended to assure him that his ideas on petroleum occurrence had not been corrupted, and as an example of how the Survey might publish on subjects of public interest. Despite his dismal prospects in Lambton, Bell maintained enough interest in petroleum to purchase lots in Manitoulin's Wikwemikong, Sheguindah and Billings Townships, presumably not in his own name as public servant, but drilling there never showed much promise.

\section{Scotian Gold The Goldfield}

More promising, at least at the outset, were Bell's involvements in gold-mining developments while he was a Queen's University professor between 1864 and 1868. Confederation was an economic shot-in-the-arm for Nova Scotia, although the arm also bled. One of the gains was investment from Ontario in its mines - iron ore, coal, and gold. After the original Gold Rush in California in 1849, and others it spawned, especially in the Middle Fraser and Cariboo District of the colony of British Columbia, gold was to the fore in the minds of speculators everywhere.

Gold-bearing quartz was easily recognized, and peninsular Nova Scotia was full of it. Veins commonly protruded through the forest floor and through the sod of deforested lands, and were easily followed across country. The Scotian gold-field itself occupied a belt of low-grade metamorphic rocks along the Atlantic coast between Halifax and Canso (Fig. 2c), rocks now known as the Meguma Group. They included the Goldenville Series, mainly sandstones, and the Halifax Series, mainly slates, both of Early Paleozoic age, roughly 550-400 Ma, which were deformed, heated and intruded by granitic magmas soon after, during the 'Acadian' orogeny at $\sim 350 \mathrm{Ma}$. Gold veins are concentrated along the crests of up-folds in the slates, where the rock was stretched, opening fractures penetrated by silica- and gold-rich fluids believed in these early days to have been derived from granitic magma.

1858 is usually taken as the year gold was discovered in Nova Scotia, and Tangier, northeast of Halifax (Fig. 2c), as the place (geological information here is after Heatherington 1868, Selwyn 1872 and Bates 1987; while Hind 1870 is noted as a commercially-driven exaggeration of gold potential). Veingold is more abundant by far than placers. Veins are centimetres to metres thick, 100's of metres to kilometres in length, extending up to $200 \mathrm{~m}$ below the surface, and are gently inclined, sub-parallel to the original stratification of Meguma sedimentary rocks, which have been over-folded to the northwest. Veins were therefore difficult to mine, especially by inexperienced workers, as shafts had, of course, to follow the veins. 
Drainage was always a problem - at worst, costing as much as extraction. Vein-rock had to be crushed, but only found its way to the crusher if gold was visible, so more than half of its content was missed, although it was sometimes regained later when old tailings were crushed finer and more efficiently leached.

Primitive though mining was in Nova Scotia, the economic environment surrounding it was worse. Under-capitalization was the main problem, since machinery had to be purchased, delivered, erected, and worked efficiently, none of which could be performed easily by inexperienced local labour; experienced labour had vanished westward. Interruption of funding was most sorely felt by drainage operations; when they ceased, time and money had to be spent on re-draining before extraction resumed. Water supply was the next problem - too much water below, often too little above for sluicing and washing. Dam a stream - time and money; divert a stream - time and money. Power to drive machinery was next - was stream power close enough to the gold workings? If not, only coal could fuel traction engines to raise rock from the shafts, haul wagon-loads to the crushers; and coal was miles away in Cumberland County.

For eager investors, profits were easy to predict based on simple arithmetic. Costs of crushing were between $50 \phi$ and $\$ 3.00$ a ton, when the average share cost was $\$ 1.50$, so large investments were necessary. If a mine attracted 2000 shares (say, \$3000), with gold in the world market fetching betweeen $\$ 20$ and $\$ 50$ an ounce through the 1860's that investment would have to be matched by only between 3 and 7 tons of rock crushed yielding $20 \mathrm{oz}$. per ton. Open-air crushing could continue for 10 months of the year - say 250 days - and yield 10 tons crushed per day. If 20 ounces could be extracted from each ton, \$1-2.5 million was the potential annual gross revenue. Again, for the potential investor half of that was predicted as profit, after taxes, equipment, and wages.

But this potential was never realized; properties were small and scattered, workers inexperienced, investors were shy; too much went on promotion over extraction and processing. Over all districts average annual yields per worker were $\$ 517.32$ (Heatherington 1868 , p. 90 ) - around $\$ 2000$ to $\$ 2500$ per mine - so, even with 10 mines per district, this was a pitiful $1 / 1000$ of the potential calculated above. While economic prospects did improve throughout the 1860 's, the under-performing Nova Scotia 'Gold Rush' ended with a whimper the following decade.

Correspondence reveals that Robert Bell was involved in all ten Nova Scotia gold properties, as geological consultant to a group of Kingston investors comprising Queen's faculty and administrators, as well as lawyers and businessmen in the town. He also consulted for Carlos Pierce, owner of gold mines at Stanstead, Québec, whose New York and Sherbrooke Company acquired, in all, 40 gold properties, containing approximately 25 workable lodes. The Scotian properties were all at places extant today: Sherbrooke and Mulgrave, Guysborough County; Wentworth, Cumberland County (placer); Eureka, Pictou County; Victoria Mines, Cape Breton County; Lawrencetown, Salmon River (-Bridge), Tangier, Montague Gold Mines, and Musquodoboit (placer), Halifax County. None is mined today, although, with gold at more than $\$ 1000$ an ounce, exploration continues.

\section{Legal Trouble}

Throughout the latter 1860's, Bell's geological appraisals and financial intermediations related to the Scotia gold properties landed him in a quagmire of debt, dubiety, and political dirt. He often had to borrow from relatives and friends the funds necessary for the initial development of properties in order to attract investors. A property suddenly went dead when workers walked away for lack of wages, or when the shaft flooded for want of a pump. Loans were called in, promissory notes were written, cheques were refused at banks. Ultimately, all accusing fingers pointed at Bell. One Kingston investor ranted, "I have been pulled and milked with a vengeance," calling Bell "unreasonable" for demanding more time and more money to oil the wheels of development. "Mr. Patton and others say that you are playing with me in the matter, and deceiving me as to the true position." (LAC, RB Papers, v. 31.60, J. Romanes to RB, 22 December 1869). John Paton, Queen's University comptroller, whose relations with Bell were never very cordial, had slighted Bell's character in an angry communication with Bell's main 'partner,' James Patton, a Kingston lawyer and future partner of another Kingston lawyer, John A. Macdonald. Bell, always quick to turn high dudgeon on an adversary, demanded that Paton withdraw the defamation, or his involvement in the scheme would be revealed (LAC, RB Papers, v. 29.36, RB to Jas. Paton, 16 July 1868). Paton responded meekly: "The remarks injurious to your character which I heard in connection with your report on the Mulgrave Gold Mine I believe to be untrue and I also believe the source from which they originated to be totally unreliable." (LAC, RB Papers, RB's copy of JP's letter, n.d.)

The failure in 1867 of the Commercial Bank, headquartered in Kingston, and source of many of the loans to local investors, contributed significantly to the financial mess in which Bell found himself. His dire financial situation, which was prolonged beyond the climax of speculation in the Scotian goldfield, is best illustrated by the contents of a letter responding to his call for clarification and advice made of his friend the prominent former journalist, now politician, William McDougall:

"I have papers, writs, bonds es which show:

(i) your partnership [with Jas. Patton] began Oct 4 1867, as shown by a co-signed agree-ment between you both, and J. Carruthers and Jas. Romanes [Kingston lawyers],

(ii) that you signed bonds and agreements to third parties jointly with Patton as late as 10 Sept 1868,

(iii) that you gave Patton power-of-attorney October 1, 1868 authorizing him to sign your name to bonds, notes, Ec for your joint affairs in Nova Scotia,

(iv) that your agreement for dissolution was not made until 13th Jannary 1869,

writs issued against you and Patton by Romanes, Ferguson, J.A. Macdonald [yes, Him!], were on account of transactions during the partnership [i.e. before January 13 1869] and are not affected in law by any agreement you \& Patton have between yourselves. ... From all of which, it follows that you are personally liable in respect of all these liabilities still unsatisfied."(LAC, RB Papers, v. 25.15, WMcD to RB, 12 May 1876).

One case of Bell's 'enthusiastic' geological appraisals of a Scotian gold property at Eureka is documented, in which Toronto brokers Osler and Pellatt were disappointed at the performance compared with Bell's forecast of success. (LAC, RB Papers, v. 29.3, E. Osler to RB, 26 August 1868). 
Some officers at the Geological Survey were concerned by what they were hearing about Bell's involvement in mining affairs. Hugh Vennor, hired to the Survey in 1866 on Bell's recommendation, wrote to Bell: "Sir William has an idea that you are in some way interested in it [a mine on Lake Superior, probably Silver Islet, off Port Arthur] and others [mines]. Mr Richardson asked me if you were engaged yourself in mining operations in answer to which I pleaded perfect ignorance. If you are doing anything in that line for yourself, you perhaps had better keep it dark from the Survey office - that is if you care at all for said office." (LAC, RB Papers, v. 37, HGV to RB, 14 December 1867); wise counsel, indicative of the loyalty that staff felt towards the Survey and 'The Chief.'

Not that Robert Bell felt differently; he took second place to no-one in institutional loyalty. The situation had, after all, arisen before he joined the permanent staff, during his Queen's professorship. He had found little guidance in the behaviour of many of his colleagues there, as well as that of other prominent citizens of Kingston. He had pursued his social and financial ambitions, striking out on a path he saw leading to relative wealth, from a position which gave him access to many whose like ambitions were more commensurate with their resources. He had been drawn into a tangled web by circumstances which allowed associates to run for cover, leaving him exposed.

\section{A Deal with John A.}

Legal 'bat-and-ball' dragged on until 1872, when, if all the foregoing wasn't enough, Bell's career progress at the Geological Survey, which he had rejoined as full-time officer in the Spring of 1869, became a bargaining chip in the resolution of guilt and debt, particularly between him and James Patton, by this time a Member of Parliament. When the colony of British Columbia bid for entry into Confederation in 1871, Bell was among those quick to realize that a geological survey was going to be needed to assess its mineral resources. Bell foresaw the need, and played a part in acquiring for the Survey an additional $\$ 19,000$ to support the survey of British Columbia and Yukon together as a package (LAC, RB Papers, v. 24.95, RB to JAM, 30 June 1871). Was this another reflection of Bell's drive to pecuniary advantage? He sorely needed to claim as his own some such potentially important territory as British Columbia, as his field experience so far had not been financially promising (in Ontario, with oil and iron ore; in Nova Scotia with gold (and coal?); in Newfoundland with several mineral and timber prospects). GSC Director Selwyn likely found the case for sending Bell to British Columbia unarguable; the farther away, the better, perhaps, considering Bell's early hostility to Selwyn as a British interloper, whose appointment could only discourage young Canadians of scientific bent from opting for geology as a career.

Some believe, but rarely give voice to the claim that after his visit to the western plains in 1873, Selwyn was under threat from Sir William Dawson, who had promised that unless Selwyn reserved the geological survey of British Columbia for his son, George upon his return from London, he would expose (public servant) Selwyn's purchase of land on the western plains (even if in his sons' names), on which on Selwyn's instructions borings were sunk near Fort Pelly in east-central Saskatchewan, intending to locate coal beds, but instead had proven the existence of oil.
In 1872, Principal Dawson's son, George, at the age of 23, had just returned from the Royal School of Mines in London, where he had gained the equivalent of a BSc, as well as prestigious medals. After brief teaching and consultancy assignments, in 1873 he was recommended by Sir William Logan as geologist attached to the Canadian government's survey of the Canada-USA boundary between Lake of the Woods and the Rocky Mountains. Dawson acquitted himself admirably in that work, which occupied him in summer fieldwork in 1873 and 1874, and writing up his findings in 1874-75 (G.M. Dawson 1875). The work also prepared him for the next step - westward to $\mathrm{BC}$ - where he was to spend four years forging for himself a sterling reputation within Canadian geology, a reputation that remains largely untarnished to this day (Brookes 2002). Bell, 35 years old in 1876, who had been with the Survey for 18 years, was shut out. This slight was to poison for all time his relations with George Dawson, who under Selwyn became his superior on staff, and in 1895 succeeded Selwyn as Survey Director.

Doubt is thrown upon Wiliam Dawson's threat over Selwyn by evidence that Bell had been turned down for the British Columbia work by mid-1871, before Selwyn's 1873 excursion to the plains. Bell had then written to Prime Minister John A. Macdonald, telling him how disappointed he was with the British Columbia decision (thus, not made with George Dawson on hand, but maybe in mind), and that he felt that knowledge of his dubious dealing with the mining industry was behind his disfavour (LAC, RB Papers, v. 24.95, RB to JAM, 30 June 1871). This seems, rather than involving Dawson Sr., to emphasize Macdonald's role in denying British Columbia to Bell (perhaps because Sir John, too, had been burned in Nova Scotia). There were plainly patronage-related reasons for that; Bell was known as a staunch Liberal, whereas the Dawsons were loyal to Macdonald's Conservatives. Further, it might remove both Dawsons from the equation, unless, as is certain, Dawson Sr. had plans for his son ahead of his return from London.

Even that does not quite settle the matter. Correspondence related to the difficulties Bell faced in Nova Scotia reveals additional bargaining chips he and his lawyers brought to the table in his quest for the British Columbia position. First, at quite a late stage in the proceedings, in order to keep his name off the record, Bell invented a player to whom he gave the name 'J. McNulty' as a 'nom-de-plume' in correspondence concerning legal settlement of scores between himself and James Patton, towards whom Bell had acted in what many would call a reckless manner. Bell (as 'J. McNulty') wrote to his lawyers Osler and Regue, enclosing \$5000 in promissory notes he had previously received from Patton, "to be held by Osler for McNulty as his property and to be returned when called for, until McNulty received the appointment applied for from the Dominion Government as head of the Geological Survey of British Columbia, and in this event you are authorized to give up such notes cancelled and paid to the Hon. James Patton of Kingston." (LAC, RB Papers, v. 29.1, 'McNulty' [RB] to BB Osler, 18 February 1872).

Patton, a prominent lawyer, a Member of Parliament, and friend and future law-partner of John A. Macdonald, could not come out of the case with any blemish on his reputation. To this end he enlisted Macdonald to engineer an agreement with Selwyn at the Survey, that Bell would be assigned the British 
Columbia work if he would 'take the fall,' leaving Patton blameless in the financial imbroglio. Bell, meanwhile, did some 'engineering' of his own in handing to his lawyers the $\$ 5000$ in promissory notes made out by Patton to various creditors, on the understanding that they would be called, unless Bell received the British Columbia posting from the Dominion government:" $[\mathrm{O}]$ n receiving this position I will discharge the debt of James Patton ... and will assist you [the lawyers] in the discharge of liabilities to Messrs Machar, Romanes, Carruthers [Queen's University 'worthies'], and others, for which I am said to be liable." (LAC, RB Papers, v. 29.1, RB to BBO, 1 March 1872). Osler recommended to Bell, "Do as I suggest [regarding the promissory notes, as above $]$ and I assure you from confidential sources that your appointment [to BC] is secure." (LAC, RB Papers, v. 29.1, BBO to RB, 7 March 1872).

Both Patton and Bell, then, appear to have been working to the same end, both ignorant of any influence Dawson pére might have had over Selwyn in filling the British Columbia position. Yet, Bell was not appointed to it, so what went wrong with the proposal engineered by Macdonald? Bell told Osler that he wasn't going through with the deal they had agreed. Osler then reminded Bell that Patton had the upper hand with Macdonald, who, he said, could appoint or dismiss him. Urging Bell to meet Patton halfway, he ended, "If on receipt of this you continue in the same mind, I wash my hands of the consequences and will at once return the notes and the undertaking to you" (op. cit.).

\section{A Narrow Escape}

With Bell standing down against Patton, Patton was out financially only to the extent of his legal costs, which he recovered from Bell in a Montréal court, away from Kingston and Toronto headlines. Apparently, it was left there, both walking away scathed, but relieved it wasn't worse. Patton had sufficient influence to ride out suspicions and whispers. Bell, however, it is fair to say, was left scarred for life, first by his Nova Scotia dealings, and then by the British Columbia affair. When Dawson Jr. was 'assigned' the British Columbia work in 1875, Bell lost professional territory as well as status. His subsequent difficulties at the hands of Ministers (including Laurier as well as Macdonald) and competitive colleagues (Low and Brock in particular) may have owed something to the fact and legend of the Nova Scotia mining débacle, handed down unspoken through the next three decades of his career.

It will be obvious by now that none of Bell's scientificcum-commercial ventures had succeeded.

\section{CONCLUSION \\ Scientist Bell}

For the remaining 35 years of his career at the Survey, Bell subserviated financial ambition to science, as field evidence accrued. He explored all of the north-draining major rivers of Ontario, (except the Winisk and Severn Rivers), and neighbouring northeast Manitoba (Nelson-Hayes and Churchill) and northwest Québec (Harricanaw, Nottaway, Rupert) (Bell 1872 a, b, 1873, 1874, 1877, 1878, 1879, 1880, 1881, 1883 a, b, 1887, 1901a). On several of these explorations, he recorded driftfilled palaeochannels in riverbanks, which later gained him recognition as the first to posit the existence of a pre-glacial drainage system across boreal Canada (Bell 1895), the stem of which was named 'Bell River' by McMillan (1973, p. 504-505).
Bell's paper, On Glacial Phenomena in Canada (Bell 1890), based on evidence obtained on these explorations marked the 'vestibule to modernity' in these studies - a sub-continental synthesis unique at the time and the most significant Canadian advance since Logan's (1847) first acceptance of glacial action in Canada. From those northern explorations Bell offered voluminous evidence from striae and till/erratic provenance of sub-continental ice-sheet flow-fields, leading him to the first identification of the Hudson Bay depression as a collection basin for ice-flows from Québec, Labrador, and Keewatin, delivering that ice southwards into the United States and eastwards in what he called an 'ice stream' through Hudson Strait to the Atlantic (Brookes 2007). The details of westward iceflows from Keewatin were the purview of his successors, McConnell (1891) and Tyrrell (1896). On his sea voyages along the Labrador coast in 1884, 1885, and 1897, Bell (1885a, c, $1901 \mathrm{~b}, \mathrm{c})$ speculated on the unglaciated status of jagged, weathered peaks of the Torngat Mountains of northern Labrador (Bell 1885a), setting off a controversy that simmers today from Baffin Island to Newfoundland.

As a by-product of these extensive travels through Canada's boreal forest, Bell produced maps of the limits of each of its tree species and an interpretive commentary (Bell 1880, 1881). The work of Blodget $(1857,1875)$ on North American climate had become well-known by this time, particularly for its revelation in isothermal and isohyetal patterns of sub-continental influences of latitude, the western mountains, and Hudson Bay. Bell was thus able to relate the first-order patterns of tree limits to these first-order factors. But, he went further in considering historical competition among different trees, as well as fire history and tree-succession (Bell 1889, 1906). Bell's lesser-known works on forest subjects has earned him Nestorian status; no less a modern authority than Stephen J. Pyne devotes a chapter of his fire history of Canada (Pyne 2007) to joint consideration of Robert Bell and Bernhard Fernow (late of University of Toronto's Forestry Department) as doyens of the subject. For example, on Bell:

"Robert Bell was ... perhaps the last man to have the opportunity to tramp over vast stretches of the Canadian outback while possessing the training to report in scientific language what he saw and commanding the institutional setting to make bimself heard...

- He accomplished for the Canadian north what Humboldt did for the South American tropics.

... he recognized that fire was not merely a seasonal presence, like mosquitoes, but a shaper of the vast northern forests, a force as powerful as the droughts and winds with which it was associated." (p. 147).

By corporate invitation, Bell was also very much involved in plans for a railway from The Pas, Manitoba, to a proposed trading post at Fort Churchill or York Factory on Hudson Bay, for which he surveyed thousands of kilometres of what is now northern Manitoba, including detailed plans of the NelsonHayes and Churchill River systems (Bell 1879, 1880). For this project he also made terrestrial and marine observations while acting as scientific and medical officer on three of four Canadian government shipboard expeditions commissioned to investigate sea-ice conditions affecting navigation in Hudson Strait and Bay (Bell 1885, 1901b). His case in support of the opening of a port at Churchill (Bell 1910) is a model of subcontinental economic geography, at the dawn of that sub-dis- 
cipline (Clark et al. 2000). He was the first geologist to describe the Athabasca bituminous sands (Bell 1883c, 1885b), and early recognized their economic potential (Bell 1883c, 1908).

Bell authored 32 GSC reports (including four long 'Summary Reports of the Acting Director'), 111 papers in journals (including a few abstracts), 17 solo-authored geological maps (roughly equivalent to GSC's coloured 'A' series), 46 other geological, topographical, and cadastral maps as senior author, 38 maps as junior author, and gave 103 conference papers and lectures to natural history, historical, and charitable societies.

\section{Late Years}

GSC Director George Dawson died suddenly in his $52^{\text {nd }}$ year, on March 4 1901, from pulmonary complications of a chest cold. Robert Bell, who turned 60 three months later, and who had then been with the Survey for almost 40 years (accounting for the 5 years at Queen's University), was appointed to replace him. There was no one else on staff with the combined seniority and respect among staff to be considered a candidate. Frank Adams at McGill and Willett Miller at what was then Kingston School of Mining were 'unavailable.' Given, therefore, that Interior Minister Sifton could (grudgingly perhaps) see Bell as the only choice left to him, he also saw sufficient reason to down-grade the position's title to 'Acting Director.' Sifton's reasoning, and Prime Minister Laurier's presumed consent to it (or did the word come down from the PMO?) was not a straight-forward balancing of qualification and choice; there must have been a sense of 'punishment' for the difficulties in Bell's relations with former Directors Selwyn and Dawson, the bad odour of which had pervaded the Survey for at least the past 20 years. As well, there was the suspicion, grown into certainty, of Bell's poor handling of financial affairs, in particular those surrounding the Scotian 'gold-bust,' albeit 30 years before.

Titular dilution of Bell's promotion certainly was a political and personal slight - a festering sore over his final years with the Survey. But, Sifton knew that whatever the title Bell would acquit himself well (and, thus, the Interior Ministry), as a matter of professional and personal pride. On 'The Hill' one imagines chuckles behind closed doors: 'five years as Acting Director and we'll be shot of him.'

Then, in 1902 Sifton found it necessary to mollify relations between Bell and the Liberal Government, whose colours Bell had flown lifelong. He offered Bell a pre-retirement sinecure as Chief Curator of the proposed new Victoria Museum, on the condition that he retire after five years (RBP, v. 33.16, CS to $\mathrm{RB}, 17$ July 1902). Bell refused it, preferring to pursue what he considered his due - the 'Real' Directorship (and the hind-cast deficit in pay compared with Dawson's), while the Museum (now occupied by the Canadian Museum of Nature) was, in the event, not completed until 1912, four years after his superannuation.

'Acting' or not, Director Bell did achieve much by way of hiring scientific staff (including R.A. Daly and W.A.J. Johnston), quick announcement (in Director's reports) and publication (in staff reports) of Survey results, the latter being the only significant recommendation of an 1884 Commons Committee which had investigated Survey affairs. As well, he increased the pay of support staff, and won increased library resources at a time of burgeoning book and journal titles.
At root, Bell's problems throughout his career lay in his mercurial professional nature and behaviour - quite the opposite of the staid, politically malleable official preferred by governments. For all of his burdens, nevertheless, he was fortunate to find relief within the family and its expanded relativesby-marriage.

In retirement Bell briefly revived his financial ambition in prospecting. For two years, he and his son, who was at the time studying mining engineering at McGill (1908-1912), prospected around Gowganda, Ontario, for extensions of Cobalt silver veins. But then, he was enticed into prospecting for an American company that claimed to have met with success for investors in silver-mining at the Comstock lode, in Nevada. After the first year, whether Bell recognized it or not, he was knee-deep in false claims of a 'Mesabi Range' of iron-ore north of Kingston. To draw attention away from his name, this was when he drew upon his McNulty 'nom de plume' again, 40 years after the Scotian gold-bust! What must have begun as a natural desire to maintain economic and social status by supplementing his superannuation of two-thirds of his prior income, must have retained some honest rationale - perhaps, at worst, he felt driven to show that 'I'm not finished yet!' When the cruel truth dawned of his (unwitting?) participation in a mining investment fraud, he and Agnes decamped to Europe for two years (1912-14), while a New York court sentenced the American principals to prison terms.

Returned to Canada, Bell lived out his final five years - winters at home in Ottawa at 136 MacLaren, summers at his property overlooking the Assiniboine River near Portage-la-Prairie, Manitoba, which he had purchased in his father-in-law's name in 1873. He and the family sorted, containered, and labelled the huge collection of materials he had amassed over fifty years at the Survey. He died June 18, 1917, six days after a stroke or cerebral hemorrhage - the death certificate called it 'Apoplexy.' He had just turned 76 and was buried temporarily in Winnipeg's Elmwood Cemetery. After settling their Manitoba affairs, his wife Agnes had his remains moved to Montréal's Mount Royal Cemetery, where a prism of polished red granite, engraved with several (not all) Bell family names, lies askew in the grass on a shaded hill slope.

\section{ACKNOWLEDGEMENTS}

The paper derives from a biography of Bell researched mostly at Library and Archives Canada, where staff were, and continue to be, efficiently helpful. Joan Ritcey, Head of the Centre for Newfoundland Studies at Memorial University of Newfoundland, was, especially in the present context, a gold-mine; as was Tracy Lenfesty, Librarian, Nova Scotia Department of Natural Resources. Ms. C. King, Cartographic Office, York University, produced Figure 2. Thorough reviews of the manuscript were provided by R.W. Macqueen, Geological Survey of Canada, and an anonymous reader.

\section{REFERENCES}

Bates, J.L.E., 1987, Gold in Nova Scotia: Nova Scotia Department of Mines and Energy, Mineral Resources Branch, Information Series ME 13, Halifax, NS (updated 2001-2005), $48 \mathrm{p}$.

Bell, R., 1858, On the fauna of portions of the Lower St. Lawrence, the Saguenay and Lake St. John: Geological Survey of Canada, Report of Progress for 1857, p. $95-108$.

Bell, R., and d'Urban, W.S., 1859a, Catalogue, with notes, of the animals and plants collected and observed by R. Bell on the southeast side of the St. Lawrence from Quebec to Gaspe, and in the counties of Rimouski, Gaspe, and Bonaventure: Geological Survey of Canada, Report of Progress for 1858, Appendix V, p. 243-263.

Bell, R., 1859b, On the natural history of the Gulf of St. Lawrence and the distri 
bution of the mollusca of eastern Canada: Canadian Naturalist and Geologist n.s., v. 4, p. 197-220, 241-51.

Bell, R., 1861a, List of plants collected on the south and east shores of Lake Superior and on the north shore of Lake Huron, in 1860: Annals Botanical Society of Canada, v. 1, p. 67-78.

Bell, R., 1861b, Supplementary list of trees and shrubs found growing around Lakes Superior and Huron: Annals Botanical Society of Canada, v. 1, p. 78-80.

Bell, R., 1861c, On the occurrences of fresh-water shells in some of our post-Tertiary Deposits: Canadian Naturalist and Geologist, v. 6, p. 42-51.

Bell, R., 1861d, List of recent land and fresh-water shells collected around Lake Superior and Huron in 1859-1860: Canadian Naturalist and Geologist, v. 6, p. 268-70.

Bell, R., 1861e, Catalogue of birds collected and observed around Lakes Superior and Huron in 1860: Canadian Naturalist and Geologist, v. 6, p. 270-275.

Bell, R., 1865a, On the occurrence of petroleum in Gaspe (with C. Robb): C.S. Westcott \& Co., New York, [title unknown].

Bell, R., 1865b, The oil regions of Gaspe: John A. Gray \& Green, New York, [Title unknown], $60 \mathrm{p}$

Bell, R., 1865c, The Enniskillen oil region: London. [publisher and pages unknown].

Bell, R., 1870, On the geology of the Manitoulin Island Group: Geological Survey of Canada, Report of Progress for 1866-69, p. 165-179.

Bell, R., 1872a, Report on the country north of Lake Superior, between the Nipigon and Michipicoten Rivers, Ontario: Geological Survey of Canada, Report of Progress for 1870-71, Part VIII, p. 322-51.

Bell, R., 1872b, Report on the country between Lake Superior and the Albany River, Ontario: Geological Survey of Canada, Report of Progress for 1872-73, Part III, p. 101-114.

Bell, R., 1873, Report on the country between Lake Superior and Lake Winnipeg: Geological Survey of Canada, Report of Progress for 1872-73, Part V, p. 87 111.

Bell, R., 1874, Report on the country between Red River and the South Saskatchewan, with notes on the geology of the region between Lake Superior and Red River: Geological Survey of Canada, Report of Progress for 1873-74, Part III, CC, p. 66-90, 1 Appendix.

Bell, R., 1877, Report on an exploration in 1875 between James Bay and Lakes Superior and Huron: Geological Survey of Canada, Report of Progress for 1875 76, Part XIV, p. 294-342.

Bell, R., 1878, Report on geological researches north of Lake Huron and east of Lake Superior: Geological Survey of Canada, Report of Progress for 1876-77, Part IX, p. 193-220.

Bell, R., 1879, Report on the country between Lake Winnipeg and Hudson Bay: Geological Survey of Canada, Report of Progress for 1877-78, v. 3, Part CC, p. $1-31$.

Bell, R., 1880, Report on explorations on the Churchill and Nelson Rivers, and around Gods and Island Lakes; with notes on the northern limits of forest trees: Geological Survey of Canada, Report of Progress for 1878-79, v. 4, Part C, p. 1-44, 7 Appendices; includes The Water Supply of the City of Winnipeg.

Bell, R., 1881, Report on Hudson Bay and some of the lakes and rivers lying to the west of it: Geological Survey of Canada, Report of Progress for 1879-80, Part IV C, p. 1-56, Appendices I-XI; includes "The northern limits of the principal forest trees of Canada, east of the Rocky Mountains," p. 38-56 and GSC Map 153.

Bell, R., 1883a, On the geology of the basin of the Moose River and Lake of the Woods and adjacent country: Geological Survey of Canada, Report of Progress for 1880-81-82, Part C, p. 1-9.

Bell, R., 1883b, On the geology of the Lake of the Woods and adjacent country: Geological Survey of Canada, Report of Progress for 1880-81-82, Part CC, p. 11-15, 2 Appendices.

Bell, R., 1883c, On the occurrence of petroleum in the North-West Territories, with notes on new localities: Proceedings of the Canadian Institute, series III, v. 1, p. $225-230$.

Bell, R., 1885a, Observations on the Labrador coast, Hudson Strait and Bay: Geological Survey of Canada, Report of Progress for 1882-83-84, n.s., v. 1, Part DD, 37 p., 5 Appendices.

Bell, R., 1885b, Report on part of the basin of Athabasca River, North-West Territory: Geological Survey of Canada, Report of Progress for 1882-83-84, n.s., v. 1, Part CC, 35 p., 1 Appendix.

Bell, R., 1885c, Report on the geology of Hudson Bay and Strait, in Report of the Second Hudson Bay Expedition under the command of Lt. A.R. Gordon, R.N. 1885: Ottawa: Department of Marine and Fisheries.

Bell, R., 1887, Report on an exploration of portions of the Attawapiskat and Albany Rivers, Lonely Lake to James Bay in 1886: Geological Survey of Canada, Annual Report, n.s., v. 2, Part G, 38 p., 1 Appendix.

Bell, R., 1889, Forest fires in northern Canada: Proceedings of the American Forestry Congress, Atlanta, 1888, 7 p.

Bell, R., 1890, On glacial phenomena in Canada: Geological Society of America Bul- letin, v. 1, p. 287-310, http://dx.doi.org/10.1130/GSAB-1-287.

Bell, R., 1895, A great pre-glacial river in northern Canada: Scottish Geographical Magazine, v. 13, p. 368-372. (Also abstract in Transactions of the Royal Society of Canada, ser. 2, v. 2, 1895).

Bell, R., 1901a, On the geology of the basin of the Nottaway River, with a map of the region: Geological Survey of Canada, Annual Report for 1900, n.s., v. 13, Part K, 11 p.

Bell, R., 1901b, On an exploration on the northern side of Hudson Strait: Geological Survey of Canada, Annual Report for 1898, n.s., v. 11, Part M, 32 p., 3 Appendices.

Bell, R., 1901c, A survey in Baffinland, with a short description of the country: The Geographical Journal, v. 18, p. 25-43, http://dx.doi.org/10.2307/1775761.

Bell, R., 1906, The alarming destruction of our forests by fire: Report of the Canadian Forestry Convention, Government Printing Office, Ottawa, p. 29-34.

Bell, R., 1908, Tar sands of the Athabasca River: Transactions American Institute of Mining Engineers, v. 17, p. 157-169.

Bell, R., 1910, The Hudson Bay route to Europe: Scottish Geographical Magazine, v. 26, p. 67-76, http://dx.doi.org/10.1080/14702541008554001.

Blodget, L., 1857, Climatology of the United States and of the temperate latitudes of the North American continent: Lippincott \& Co., Philadelphia, 538 p.

Blodget, L., 1875, Climate of British North America, with isothermal and rain charts, in Walling, H.F., ed., Atlas of the Dominion of Canada: G.N. Tackabury, Montreal, $251 \mathrm{p}$

Brookes, I.A., 2002, G.M. Dawson and the glaciation of Western Canada: Geoscience Canada, v. 29, p. 169-178.

Brookes, I.A., 2007, First recognition of a Laurentide ice-stream: Robert Bell on Hudson Strait: Géographie physique et Quaternaire, v. 61, p. 211-215.

Brookes, I.A., 2010, The Geological Survey, Confederation, and economic ambition: Robert Bell in St. John's, 1869: Aspects, v. 45, p. 50-55, in The Newfoundland Quarterly, v. 102, www.infonet.st-johns.nf.ca/providers/nfldhist.

Brookes, I.A., 2011, Robert Bell's Professorship at Queen's University, 1864-1868: Geoscience Canada, v. 38, p. 175-181.

Clark, G.L., Feldman, M.P., and Gertler, M.S., 2000, Economic Geography: Transition and Growth, in Clark, G.L., Feldman, M.P., and Gertler, M.S., eds., The Oxford Handbook of Economic Geography: Oxford University Press, New York, p. 3-17.

Cuff, R., and Wilton, D., 1993, Jukes' Excursions: being a revised edition of Joseph Beete Jukes' "Excursions in and about Newfoundland During the Years 1839 and 1840:" Harry Cuff Publications, St. John's, NL, 228 p.

Dawson, G.M., 1875, Report on the geology and resources of the region in the vicinity of the Forty-Ninth Parallel, from the Lake of the Woods to the Rocky Mountains, with lists of plants and animals collected and notes on the fossils: British North America Boundary Commission, Dawson Brothers., Montreal 379 p.

Dawson, J.W., 1866, Note on the boulder drift and sea margins at Little Metis, lower St. Lawrence: Canadian Record of Science, v. 2, p. 36-38.

Harvey, M., 1873, Western Newfoundland: a new home for emigrants: Maritime Monthly, v. 1, p. 97-125.

Heatherington, A., 1868, A practical guide for tourists, miners, and investors, and all persons interested in the development of the gold fields of Nova Scotia: J. Lovell, Montreal, $177 \mathrm{p}$

Hillier, J.K., 1996, The Newfoundland Fisheries issue in Anglo-French Treaties, 1713-1904: The Journal of Imperial and Commonwealth History, v. 24, p. $1-$ 23, http://dx.doi.org/10.1080/03086539608582966.

Hind, H.Y., 1860, Narrative of the Canadian Red River exploring expedition of 1857 and of the Assiniboine and Saskatchewan exploring expedition of 1858 (2 v.): Longmans, Green and Roberts, London, (reprint, 2 vol. 1971, Hurtig, Edmonton)

Hind, H.Y., 1870, Report on the Sherbrooke gold district, together with a paper on the gneisses of Nova Scotia and an abstract of a paper on gold mining in Nova Scotia: Charles Annand (Printer), Halifax, NS, 79 p.

Howley, J.P., 1896, A historical sketch of the discovery and development of the coal areas of Newfoundland up to date (pamphlet): The Evening Telegram, St. John's, NL, 7 p.

Jukes, J.B., 1840, Report on the geology of Newfoundland: Edinburgh New Philosophical Journal, v. 29, p. 103-139

Jukes, J.B., 1842, Excursions in and about Newfoundland during the years 1839 and 1840 (2 v.): John Murray, London, 354 p., http://dx.doi.org/10.5962/ bhl.title.46697.

Logan, W.E., 1846, On the geology of the Chat and Cascapedia Rivers, Gaspe, and part of Chaleur Bay: Geological Survey of Canada, Report of Progress for 1844 , p. 5-66.

Logan, W.E., 1847, On the topography and geology of the Ottawa River and some of its tributaries, with notes on economic minerals: Geological Survey of Canada, Report of Progress for 1845-46, p. 6-98.

Logan, W.E., and Staff of the Geological Survey of Canada, 1863, Geology of 
Canada: Dawson Brothers, Montreal, 988 p. (Accompanied by atlas of maps and sections, 1865).

Martin, W., 1983, Once upon a mine: story of Pre-Confederation mines on the Island of Newfoundland: Canadian Institute Mining and Metallurgy, Special Volume 26, $98 \mathrm{p}$.

McConnell, R.G., 1891, Report on an exploration in the Yukon and Mackenzie basins, N.W.T.: Geological Survey of Canada, Annual Report, n.s., 4 (18881889), Pt. D, 163 p.

McMillan, N.J., 1973, Shelves of Labrador and Baffin Bay, Canada, in McCrossan, R.G., ed., Future Petroleum Provinces of Canada: Canadian Society of Petroleum Geologists, Memoir 1, p. 473-517.

Murray, A., 1847, On the topography and geology of portions of the north shore of Lake Huron, French River and the Manitoulin Islands: Geological Survey of Canada, Report of Progress for 1845-46, p. 99-118.

Murray, A., 1866, Report for 1865, in Murray, A., and Howley, J.P., eds., Geological Survey of Newfoundland (1881): Edward Stanford, London, p. 51-70.

Pyne, S.J., 2007, Awful splendour: a fire history of Canada: University of British Columbia Press, Toronto, 549 p.

Rowe, F.W., 1980, The French Shore, in A History of Newfoundland and Labrador: McGraw-Hill Ryerson Ltd., Toronto, Chapter 16, p. 311-325.

Selwyn, A.R.C., 1872, Notes and observations on the gold-fields of Quebec and Nova Scotia: Geological Survey of Canada, Report of Progress for 1870-71, p. 252-282.

Tyrrell, J.B., 1896, Report on the Dubawnt, Kazan, and Ferguson Rivers and the northwest coast of Hudson Bay: Geological Survey of Canada, Annual Report, 1894, n.s., 9, 218 p.

\section{Received March 2014}

Accepted as revised August 2014

\section{Memories of lan Brookes*}

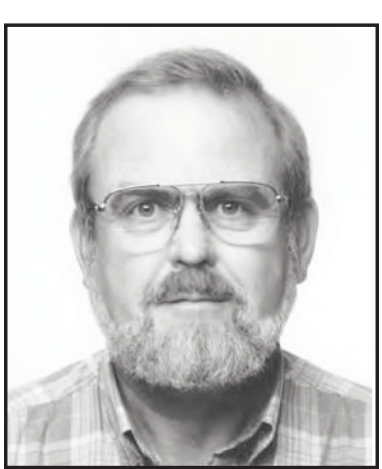

Ian and I worked together on and off for over 25 years, though I had met him much earlier in Toronto. He often stayed in our house in Woody Point during his many visits to western Newfoundland, where he had many other friends. We conversed about music, literature, history, but mostly about geology and the post-glacial history of Gros Morne National Park. It was Ian who designed the popular and now out-of-print geological map of the Park published by the Geological Survey of Canada in 1992. And it was en route to a workshop on environment monitoring in the Park that I cochaired in the 1990s that he had his first stroke, which sidelined him for several years.

He emerged from rehab somewhat disabled physically, a source of considerable frustration to him, but he was as alert as ever. He poured his energies then into researching and writing biographies of prominent Canadian earth scientists, but most of all re-working and advancing his extensive knowledge of Newfoundland landscapes. Several projects, a few of which his colleagues are now working to complete, remained unfinished at his death. Ian was a stimulating friend, though he could be crusty and quick to anger when others did not see eye to eye with him. I shall miss him.

\section{Antony Berger}

Woody Point, Newfoundland

*This memorial first appeared in Geolog, v. 44 (2), p. 29 